\title{
KALIMAT DALAM SISINDIRAN DAN WAWANGSALAN ANYAR KARYA DÉDY WINDYAGIRI (Kajian Struktur dan Semantik)
}

\author{
Hena Sumarni \\ SMP Negeri 7 Cimahi \\ Pos - el: henasum72@gmail.com
}

\begin{abstract}
Abstrak
Penelitian ini bertujuan untuk mendeskripsikan kalimat dalam sisindiran dan wawangsalan anyar. Dalam penelitian ini digunakan metode deskriptif. Untuk mengumpulkan data digunakan teknik studi pustaka. Pengolahan data dilakukan dengan menggunakan metode distribusional dengan téknik analisis unsur langsung yang diikuti oleh teknik ekspansi, permutasi dan delisi. Temuan-temuan dalam penelitian ini adalah déskripsi tentang bentuk kalimat dalam sisindiran dan wawangsalan yang berupa kalimat majemuk dengan tipe dan pola kalimat yang variatif, hubungan makna antraklausa dalam kalimat majemuk serta kekhasan-kekhasan kalimat dalam sisindiran dan wawangsalan anyar, yakni (1) bentuk kalimat berupa kalimat majemuk, (2) memiliki kebebasan dalam konstruksi (struktur) kalimat, (3) kelonggaran gaya dalam menempatkan urutan kata, dan (4) subyek sering tidak dikatakan. Kata kunci: kalimat, sisindiran, wawangsalan
\end{abstract}

\section{SENTENCES OF SISINDIRAN AND WAWANGSALAN ANYAR OF DEDY WINDYAGIRI (A Structure and Semantics Study)}

\begin{abstract}
Abtsract
This study aimed to describe the sentences in the text of sisindiran and wawangsalan anyar. The research used descriptive methods. The data collection of this study employed the techniques of literature study. The data processing was distributional method with direct elemental analysis techniques. This was followed by the techniques of expansion, permutation, and deletion. The research findings cover description of the sentence forms in sisindiran and wawangsalan. They are complex sentences containing various sentence patterns and types and meaning relations between clauses in compound sentences. It also contains peculiarities of sentence. The peculiarities are (1) the form of complex sentences, (2) the freedom in construction (structure) of sentences, (3) the flexibility of word order, and (4) the hidden subject.
\end{abstract}

Keywords: Sentence, Sisindiran, and Wawangsalan

\section{PENDAHULUAN}

Sisindiran telah lama disebut-sebut dalam sebuah naskah Sunda kuno, Sanghyang Siksakandang Karesian (1518). Pada naskah tersebut sisindiran diinformasikan dengan istilah kawih sisindiran. Uraian secara lengkapnya dapat dilihat seperti di bawah ini:
"Hayang nyaho di sakweh ning kawih ma: kawih bwatuha, kawih panjang, kawih lalaguan, kawih panyaraman, kawih sisi(n)diran, kawih pengpeledan, bongbong kaso, pererane, porod eurih, kawih babahanan, kawih ba(ng)barongan, kawih tangtung, kawih sasa(m)batan, kawih igel- 
igelan; sing sawatek kawih ma, paraguna tanya".

Terjemahan kutipan di atas adalah sebagai berikut: jika ingin mengetahui bermacam-macam jenis lagu: kawih bwatuha, kawih panjang, kawih lalaguan, kawih panyaraman, kawih sisi(n)diran, kawih pengpeledan, bongbong kaso, pererane, porod eurih, kawih babahanan, kawih ba(ng)barongan, kawih tangtung, kawih sasa(m)batan, kawih igel-igelan; maka tanyakanlah pada ahli karawitan.

Pada kenyataan dewasa ini, perkembangan sisindiran dalam kehidupan masyarakat Sunda dinilai masih produktif. Beberapa di antaranya memang dikemas dalam bentuk lagu, baik yang bergenre pop, tembang atau jenis lagu lainnya. Salah satu contohnya adalah:

Bubuy bulan, bubuy bulan sanggray béntang

Panon poé, panon poé disasaté

Unggal bulan, ungggal bulan abdi téang

Unggal poé, unggal poé ogé hadé

Bukan hanya pada sejumlah lagu dan kawih saja sisindiran dipergunakan dalam kehidupan masyarakat Sunda. Dalam kesempatan formal dan resmipun sisindiran masih banyak dipergunakan. Misalnya pada saat berpidato, ceramah keagamaan, bahkan dalam kegiatan pendidikan dan pengajaran di sekolahsekolah dan perguruan tinggi. Sisindiran yang sering ditemukan dalam kegiatan formal tersebut di antaranya sebagai penutup pidato atau selingan ceramah keagamaan:

Saninten buah saninten

Dicandak ka parapatan

Hapunten abdi hapunten

Bilih aya kalepatan

Saninten buah saninten

Dibawa ke perempatan

Maafkan saya maafkan

Kalau ada kesalahan
Sugan téh kukupu muntir

Singhoréng Si Rama-Rama

Sugan téh tungkul keur mikir

Singhoréng ngacay bahamna

Dikira kupu-kupu berputar

Ternyata Si Rama-Rama

Dikira tunduk berpikir

Ternyata mulutnya ngeces

Pesan yang dikemas dalam sisindiran dengan mudah sampai kepada para penyimaknya. Kata demi kata yang dirangkai dalam sisindiran bukanlah kalimat biasa, tetapi kalimat-kalimat yang diatur oleh ketetapan jumlah engang (suku kata). Dengan kata lain, kalimat-kalimat yang digunakan dalam sisindiran merupakan kalimat yang disusun dalam bentuk terikat. Sisindiran dalam kesusastraan Sunda termasuk ke dalam karya sastra bentuk ugeran (puisi). Hal ini menunjukkan bahwa kalimat yang digunakan dalam sisindiran merupakan kalimat-kalimat yang diatur oleh ketentuan khusus, yaitu; jumlah engang (suku kata), purwakanti sora (rima), cangkang (sampiran), dan eusi (isi).

\section{Kalimat dan Bentuk Kalimat}

Beberapa definisi tentang kalimat sudah sangat akrab dalam ingatan kita. Robins (1983: 25) menyebutkan bahwa kalimat adalah

A structure corresponding to a complete utterance, wich may be bounded by indefinite silince on either side and part of wich is in intonation tune.

Menurut Robins, kalimat dalam bahasa Sunda dapat didefinisikan sebagai struktur yang hampir sama dengan ujaran yang lengkap yang dibatasi oleh adanya jeda dan intonasi yang menjadi bagian dari keseluruhan ujaran.

Alwi (2003: 311) menjelaskan bahwa kalimat adalah satuan bahasa terkecil, 
dalam wujud lisan atau tulisan, yang mengungkapkan pikiran yang utuh. Dalam wujud lisan, kalimat diucapkan dengan suara naik turun dan keras lembut, disela jeda, dan diakhiri dengan intonasi akhir yang diikuti oleh kesenyapan yang mecegah terjadinya perpaduan ataupun asimilasi bunyi maupun proses fonologis lainnya. Dalam wujud tulisan berhuruf Latin, kalimat dimulai dengan huruf kapital dan diakhiri dengan tanda titik (.), tanda tanya (?), atau tanda seru (!); sementara itu di dalamnya disertakan pula berbagai tanda baca seperti koma (,), titik dua (:), tanda pisah (-), dan spasi. Tanda titik, tanda tanya, dan tanda seru sepadan dengan intonasi akhir, sedangkan tanda baca lain sepadan dengan jeda. Spasi yang mengikuti tanda titik, tanda tanya, dan tanda seru melambangkan kesenyapan.

Sudaryat (2014: 181) menyebutkan bahwa kalimat adalah sebuah bentuk ketatabahasaan yang maksimal dan mempunyai ciri kesenyapan final yang menunjukkan bentuk itu berakhir. Kalimat adalah satuan gramatik yang dibatasi oleh adanya jeda panjang yang disertai nada akhir turun naik (Ramlan, 1983: 6). Kalimat merupakan untai berstruktur dari kata-kata. Dengan demikian dapat disimpulkan bahwa kalimat adalah bentuk ketatabahasaan maksimal, yang disertai jeda turun naik serta mempunyai ciri kesenyapan final yang menunjukkan bentuk tersebut berakhir.
Dengan memperhatikan kesimpulan di atas, di bawah ini didapat beberapa ciri kalimat (Sudaryat, 2014: 182), sebagai berikut:

1. Tersusun dari kata atau untaian katakata, baik dalam wujud frasa atau klausa.

2. Bentuk ketatabahasaan yang maksimal, lengkap dan mandiri tanpa adanya bantuan bentuk lain untuk menjadikan bentuk itu berfungsi.

3. Mempunyai intonasi final yang menunjukkan bentuk itu telah berakhir atau selesai.

4. Dalam tuturan yang lebih luas dibatasi jeda panjang (di awal dan di akhir).

Berdasarkan ciri-ciri tersebut di atas, maka bentuk kalimat dalam bahasa Sunda seperti di bawah ini dapat dikategorikan sebagai kalimat:

1) Mangga wéh.

Silahkan saja

2) Hihh sugan téh rék naon!

Huhh dikira ada apah

3) Pokona mah cup wéh.

Pokoknya harus.

Untuk mendapatkan hasil yang lebih jelas, bagaimana bentuk kalimat dalam sisindiran Sunda terlebih dahulu akan dipaparkan tiori tentang bentuk kalimat yang digunakan dalam kajian ini. Bentukbentuk kalimat yang dimaksud dapat dilihat pada diagram di bawah ini:

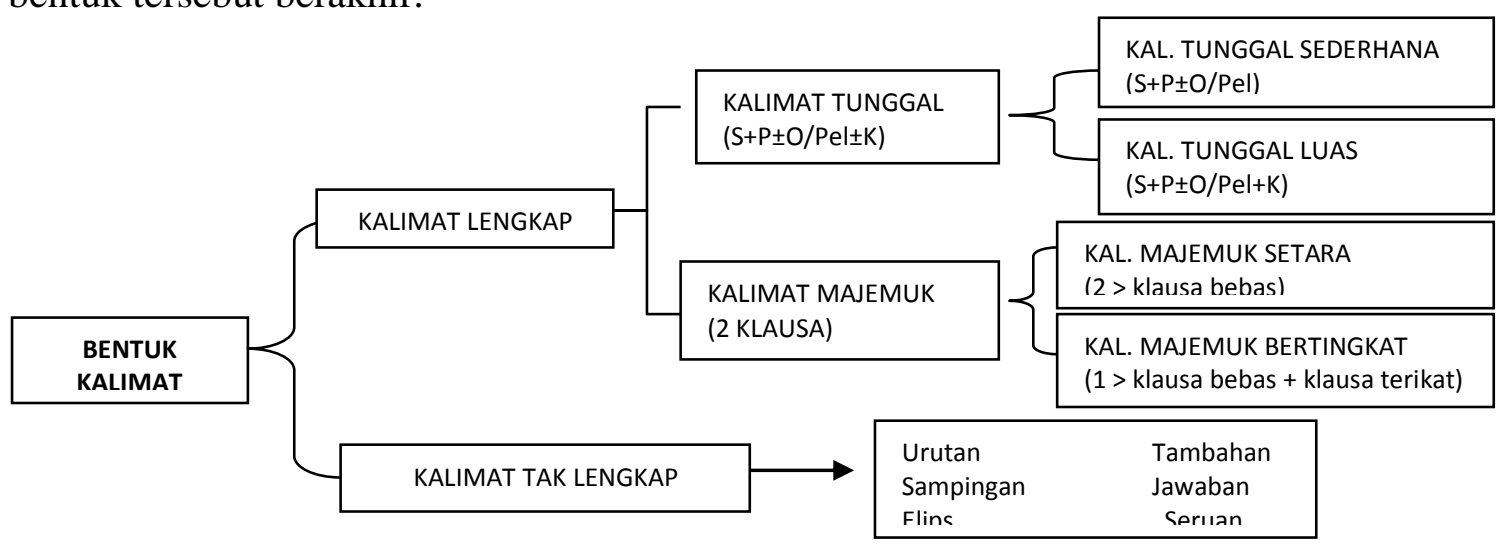

Bagan 1

(Sudaryat, 2014:18) 
Berdasarkan bagan di atas, menurut jumlah klausa yang menjadi unsur pembentuknya, kalimat dapat diklasifikasikan menjadi kalimat lengkap dan tidak lengkap.

\section{Kalimat lengkap atau kalimat sempurna}

Kalimat lengkap atau kalimat sempurna adalah kalimat yang berklausa yakni tersusun dari subjek (S) dan predikat $(\mathrm{P})$, baik disertai objek $(\mathrm{O})$, pelengkap $(\mathrm{Pel})$, dan keterangan $(\mathrm{K})$ maupun tidak.

Kalimat lengkap dapat dibedakan atas kalimat tunggal dan kalimat majemuk. Kalimat tunggal adalah kalimat yang tersusun dari sebuah klausa bebas, yakni klausa lengkap yang tersusun dari S-P, baik disertai $\mathrm{O}$, Pel, dan $\mathrm{K}$ maupun tidak. Kalimat tunggal yang tersusun dari sebuah S-P, baik disertai $\mathrm{O}$ atau Pel maupun tidak, tanpa diikuti oleh $\mathrm{K}$, disebut kalimat tunggal sederhana sedangkan kalimat tunggal sederhana yang disertai oleh $\mathrm{K}$ baik yang berbentuk frasa atau kata disebut kalimat tunggal luas.

Selain kalimat tunggal, kalimat majemuk termasuk ke dalam kategori kalimat lengkap. Kalimat majemuk adalah kalimat yang tersusun dari dua klausa. Kalimat majemuk yang tersusun dari dua buah klausa bebas atau lebih disebut kalimat majemuk setara, sedangkan yang tersusun dari satu klausa bebas, dan sekurang-kurangnya satu klausa terikat disebut kalimat majemuk bertingkat. Putrayasa (2008: 55) mengemukakan bahwa yang dimaksud dengan kalimat majemuk adalah kalimat yang terdiri dari dua klausa atau lebih atau kalimat majemuk adalah kalimat yang terdiri dari beberapa klausa bebas

\section{Kalimat tak lengkap atau kalimat tak sempurna}

Kalimat tak lengkap atau kalimat tak sempurna adalah kalimat yang dasarnya terdiri atas sebuah klausa terikat, atau sama sekali tidak mengandung struktur klausa (Cook dalam Sudaryat, 2014: 185). Kalimat tak lengkap atau tak sempurna dapat dibedakan atas kalimat urutan, kalimat sampingan, kalimat elips, kalimat tambahan, kalimat jawaban, dan seruan (Tarigan dalam Sudaryat, 2014: 185).

\section{Struktur Kalimat Bahasa Sunda}

Menurut Sudaryat (2014: 6), struktur bahasa yang dalam bahasa Sunda disebut adegan basa, merupakan organisasi unsurunsur bahasa yang memiliki pola tertentu yang bersifat linear atau sintagmatis. struktur bahasa memiliki ciri-ciri, antara lain, (1) sebuah konstruksi, (2) terdiri atas konstituen atau unsur-unsur, (3) tiap konstituen memiliki kategori tertentu, (4) tiap konstituen memiliki pola tertentu, dan (5) hubungan antarkonstituen memiliki kaidah atau pola tertentu.

Berdasarkan uraian di atas, struktur bahasa meliputi adanya konstruksi, unsur atau konstituen, kategori dan pola tertentu. Dengan demikian, struktur bahasa bisa diwujudkan dalam bentuk pola-pola tertentu, dalam hal ini adalah pola-pola kalimat. Pola kalimat tersebut meliputi pola kalimat tunggal ataupun kalimat majemuk. Baik kalimat tungal sederhana maupun kalimat tunggal luas.

Menurut Sudaryat (2014: 187-199), berdasarkan strukturnya, kalimat tunggal sederhana dapat dibedakan atas beberapa pola, seperti di bawah ini:
(1) $S-P$
(2) $\mathrm{S}-\mathrm{P}-\mathrm{O}$
(3) $\mathrm{S}-\mathrm{P}-\mathrm{Pel}$
(4) $\mathrm{S}-\mathrm{P}-\mathrm{Pel}-\mathrm{O}$

Sedangkan pola kalimat tunggal luas dapat dibedakan atas beberapa pola seperti di bawah ini:
(1) $S-P-K$
(2) $\mathrm{S}-\mathrm{P}-\mathrm{O}-\mathrm{K}$
(3) $\mathrm{S}-\mathrm{P}-\mathrm{Pel}-\mathrm{K}$
(4) $\mathrm{S}-\mathrm{P}-\mathrm{Pel}-\mathrm{O}-\mathrm{K}$
(5) $\mathrm{P}-\mathrm{S}-\mathrm{K}$ 


\section{Sisindiran dan Wawangsalan}

Wibisana (2000: 431) menyebutkan bahwa sisindiran dalam sastra Sunda sama dengan pantun dalam sastra Melayu atau Indonesia. Sedangkan dalam khazanah sastra Jawa dikenal pula karangan sejenis yang disebut parikan (Soebagyo, 1992: vii).

Sumarsono dan Faturahman (2008: 87) menyebutkan bahwa sisindiran dalam sastra Sunda mempunyai bentuk dan pola yang ajeg. Bentuk dan pola tersebut digambarkan sebagai berikut: 1) dalam satu bait terdiri dari empat baris, 2) tiap baris berjumlah delapan suku kata, 3) terdapat purwakati engang (kedekatan bunyi suku kata) antara baris kesatu dan ketiga, kedua dan keempat, 4) dua baris cangkang (sampiran) dua baris berikutnya adalah isi (eusi). Contohnya:

Nangka atah rék dibeulah

Diangeun disamaraan

Satingkah saparipolah

Nyuhunkeun rido Pangéran

Nangka mentah akan dibelah

Disayur dan dibumbui

Segala tingkah dan polah

Mohon keridoan Gusti

Unsur "ajegnya" bentuk dan pola tidak ditemukan pada contoh pantun Melayu dan parikan Jawa. Unsur yang terlihat tidak ajeg pada kedua pantun tersebut (pantun Melayu dan Parikan Jawa) adalah pada jumlah suku katanya. Contoh:

Manis sungguh tebu seberang

Dari akar sampai ke pucuk

Manis sungguh mulut orang

Kita menangis jadi terpujuk

(Redaksi Balai Pustaka, 1984: 22)

Kecik-kecik isiné sawo

Beton ponggé isiné durén

Becik-becik wong dué bojo

Waton nganggé opén pengertén
Biji sawo kecik namanya

Biji duren pongge namanya

Baik-baiklah berkeluarga

Asalkan ada pengertian di dalamnya

(Soebagyo, 1992: 73)

\section{METODE}

Penelitian ini merupakan penelitian kualitatif. Sejalan dengan penelitian kualitatif, metode yang digunakan dalam penelitian ini adalah metode deskriptif. Sumber data penelitian berupa data kalimat dalam Sisindiran dan Wawangsalan Anyar karya Dedy Windyagiri. Teknik pengumpumpulan data dilakukan melalaui teknik studi pustaka sedangkan instrumen pengumpul data yang digunakan adalah kartu data. Data diolah dan dianalisis menggunakan téknik analisis unsur langsung (immediate constituent (IC) analysis). Teknik analisis unsur langsung adalah teknik dasar yang diikuti oleh téknik (1) permutasi, (2) substitusi, (3) ekspansi, dan (4) delisi (Sudaryanto dalam Sudaryat, 2014: 59).

\section{HASIL DAN PEMBAHASAN}

Data dalam penelitian ini berjumlah 377 buah data. Data tersebut terbagi ke dalam dua bagian. 159 data sisindiran dan 218 data wawangsalan. Dalam penelitian ini dibahas bentuk kalimat dalam sisindiran dan wawangsalan, struktur kalimatnya, hubungan makna antarklausa dalam kaliimat, dan kekhasan kalimat dalam sisindiran dan wawangsalan.

Dilihat dari jumlah klausa yang menjadi unsur pembentuknya, kalimat dalam sisindiran dan wawangsalan adalah kalimat majemuk. Kalimat majemuk yaitu kalimat yang tersusun dari dua buah klausa atau lebih (Sudaryat, 2014: 185). Putrayasa (2008: 55) menuliskan bahwa yang dimaksud dengan kalimat majemuk adalah kalimat yang terdiri dari dua klausa atau lebih (Verhaar, 1983: 275), atau kalimat majemuk adalah kalimat yang 
terdiri dari beberapa klausa bebas (Kridalaksana, 1982: 164).

Perhatikan contoh-contoh di bawah ini:

1) Abdi rék ka Cikapundung teu apal kiruh hilirna, abdi mah daék dicandung sok asal puguh kilirna (S/P/49/40)

Saya hendak pergi ke Cikapundung tak tahu keruh hilirnya, saya mau dimadu asalkan benar jadwal kunjungnya.

2) Abdi mah batur kapiting teu resep ka nu rayungan (S/W/109/56)

Saya temannya kepiting tak senang kepada orang yang suka ganti-ganti pacar.

Contoh (1) merupakan contoh data sisindiran. Pada bagian sampiran (cangkang) berbunyi abdi rék ka Cikapundung teu apal kiruh hilirna. Kalimat tersebut terdiri dari dua buah klausa. Klausa kesatu abdi rék $k a$ Cikapundung sedangkan klausa kedua teu apal kiruh hilirna. Begitu pula pada bagian isi (eusi). Kalimat bagian isi adalah abdi mah daék dicandung sok asal puguh kilirna. Pada kalimat bagian isipun terdapat dua buah klausa. Klausa kesatu abdi mah daék dicandung, sedangkan klausa kedua sok asal puguh kilirna. Berdasarkan jumlah klausa yang menjadi unsur pembentuknya dapat disimpulkan bahwa kalimat dalam sisindiran merupakan kalimat majemuk.

Contoh (2) merupakan contoh data wawangsalan. Pada bagian sampiran berbunyi abdi mah batur kapiting merupakan klausa kesatu dan klausa kedua adalah teu resep ka nu rayungan. Senada dengan sisindiran, kalimat pada wawangsalan juga terdiri dari dua buah klausa. Berdasarkan jumlah klausa yang menjadi unsur pembentuknya dapat disimpulkan bahwa kalimat dalam wawangsalan adalah kalimat majemuk.

Berdasarkan hasil analisis data, penelitian ini menemukan tiga buah tipe kalimat majemuk dalam sisindiran dan dua tipe kalimat majemuk dalam wawangsalan.

Kalimat majemuk dalam sisindiran terdiri dari, (1) kalimat majemuk mandiri, (2) kalimat majemuk rangkap, dan (3) kalimat majemuk campuran (kombinasi).

1) Kalimat majemuk mandiri adalah kalimat majemuk dalam sisindiran yang terbentuk dari dua buah kalimat tunggal. Baik kalimat pada bagian sampiran maupun kalimat pada bagian isi. Kalimat tunggal yang membentuk kalimat majemuk pada tipe I ini menghasilkan empat variasi, yaitu, (1) kalimat tunggal sederhana dengan kalimat tunggal sederhana, (2) kalimat tunggal sederhana dengan kalimat tunggal luas, (3) kalimat tunggal luas dengan kalimat tunggal sederhana, dan (4) kalimat tunggal luas dengan kalimat tunggal luas. Kalimat majemuk mandiri dalam sisindiran terbentuk dari kalimat tunggal sederhana dan kalimat tunggal sederhana yang digambarkan pada contoh data seperti di bawah ini:

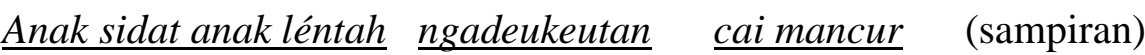 $\mathrm{S}$ \\ $\frac{\text { létah }}{\mathrm{S}} \frac{\text { ulah tisolédat ngaraheutan }}{\mathrm{P}}$ \\ $\mathrm{O}$ \\ haté batur}

Anak sidat anak lintah, mendekati air mancur, lidah jangan sampai tergelincir, menyakiti hati orang lain.
2) Kalimat majemuk rangkap (rangkepan) adalah kalimat majemuk dalam sisindiran yang terbentuk dari kalimat majemuk setara dan kalimat majemuk bertingkat. Kalimat majemuk dalam 
sisindiran tipe II ini menghasilkan dua variasi, yakni, (1) kalimat majemuk setara dengan kalimat majemuk setara dan (2) kalimat majemuk setara dengan kalimat majemuk bertingkat. Kalimat majemuk rangkap dalam sisindiran digambarkan pada contoh data seperti di bawah ini:

\section{$\frac{\text { Abdi }}{\mathrm{S}} \quad \frac{\text { rék ka Cikapundung }}{\mathrm{K}} \quad \frac{\text { hilirna }}{\mathrm{S}} \quad \frac{\text { teu apal kiruh }}{\mathrm{P}}$ (sampiran) \\ abdimah daékdicandung sokasalkilirna puguh (isi)}

2) Kalimat majemuk campuran dalam sisindiran adalah kalimat majemuk yang terbentuk dari kalimat tunggal dan kalimat majemuk. Kalimat majemuk dalam sisindiran tipe III ini menghasilkan empat variasi, yakni, (1) kalimat tunggal sederhana dengan dengan kalimat majemuk setara, (2) kalimat majemuk

Buah leutik, amis mata, jeung kanyéré $\mathrm{S}$ S

$\underline{\text { Sorangan ulah sok licik, sorangan }}$ $\mathrm{S}$ $\mathrm{P}$ $\mathrm{S}$

$\frac{\text { daék ménta embung méré }}{\mathrm{P}}$

setara dengan kalimat tunggal sederhana, (3) kalimat majemuk setara dengan kalimat tunggal luas, dan (4) kalimat tunggal luas dengan kalimat majemuk setara.

Kalimat majemuk campuran dalam sisindiran digambarkan pada contoh data seperti di bawah ini:

dikorangan $\quad$ (sampiran) $\mathrm{P}$

bertingkat. Berikut ini contoh data kalimat majemuk dalam wawangsalan tipe (1) dan (2): terbagi ke dalam dua tipe, (1) kalimat majemuk setara dan (2) kalimat majemuk

a. Kalimat majemuk tipe I dalam wawangsalan

(085) Kembang cai daun ngambang haté gegetun prihatin (S/W/79/53

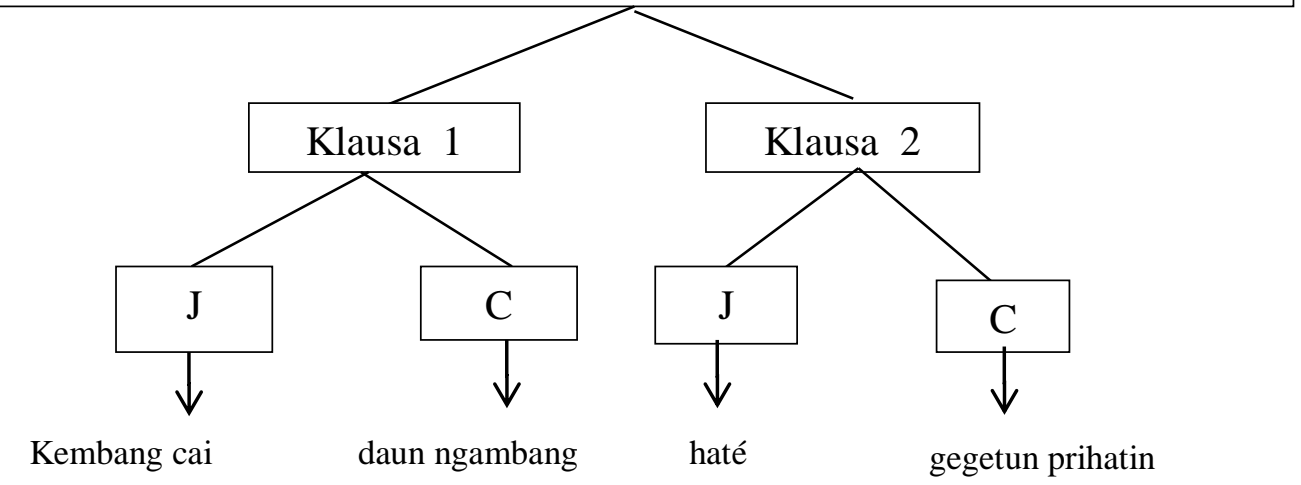


b. Kalimat majemuk tipe IIdalam wawangsalan

(012) Asa aing indung kuuk sikepna légég teu pikaresepeun (S/W/129/58)

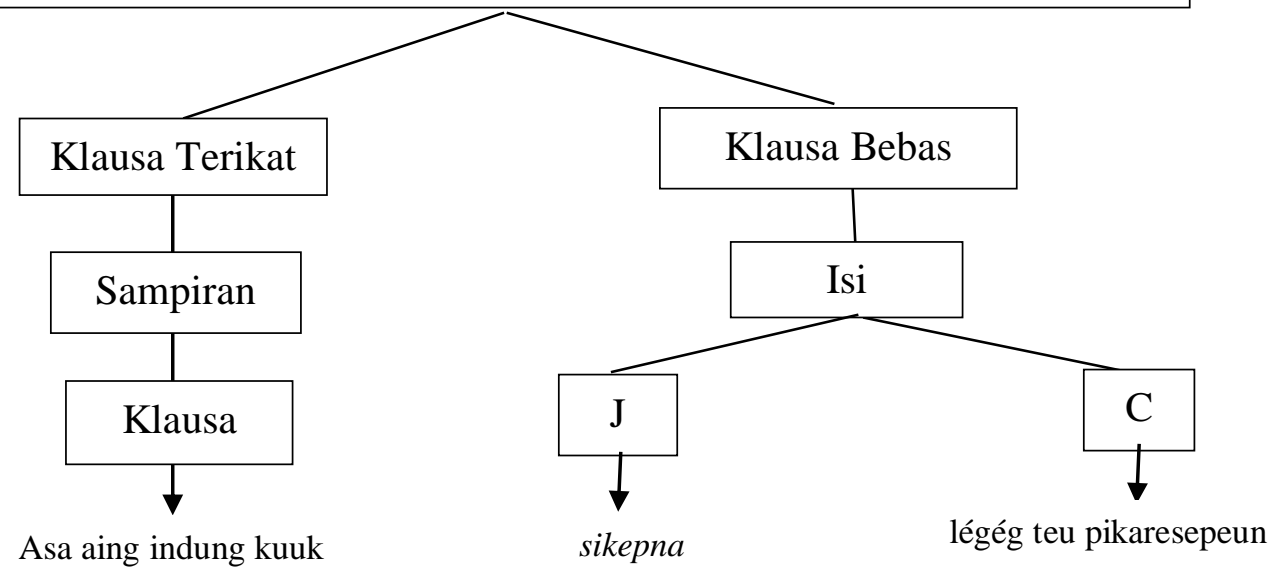

\section{SIMPULAN}

Dari uraian di atas dapat disimpulkan bahwa kalimat dalam sisindiran dan wawangsalan anyar adalah kalimat majemuk (kalimah ngantét). Sedangkan kalimat majemuk dalam sisindiran terdiri dari (1) kalimat majemuk mandiri, (2) kalimat majemuk rangkap, dan (3) kalimat majemuk campuran. Sedangkan kalimat majemuk dalam wawangsalan anyar terbagi ke dalam dua tipe, (1) kalimat majemuk setara dan (2) kalimat majemuk bertingkat. Hal ini diperoleh berdasarkan hasil analisis unsur langsung dengan teknik ekspansi, permutasi, substitusi, dan delisi. Terdapat empat hal yang menjadi kekhasan kalimat dalam sisindiran, yakni, (1) kalimat dalam sisindiran berbentuk kalimat majemuk, (2) memiliki kebebasan dalam konstruksi (struktur) kalimat, (3) mempunyai keleluasaan dalam merubah dan menempatkan susunan kata, dan (4) subjek kalimat sering tidak dikemukakan. Kekhasan dalam wawangsalan pun tidak jauh berbeda dengan kekhasan dalam sisindiran. Perbedaanya terletak pada point keempat. Jika kalimat pada kalimat dalam sisindiran unsur subjek sering tidak dikemukakan, maka subyek dalam wawangsalan sangat produktif. Penelitian ini diharapkan dapat memberi sumbangan tentang sejarah sisindiran dan wawangsalan dalam masyarakat Sunda. Bagaimana bentuk kalimat, struktur, makna antarklausa dan kekhasan kalimat dalam sisindiran dan wawangsalan yang sesungguhnya. Untuk bidang pendidikan, penelitian ini diharapkan dapat memperluas dan mewujudkan materi bahan ajar yang berkualitas serta dapat menarik minat siswa dalam pembelajaran bahasa Sunda.

\section{PUSTAKA RUJUKAN}

Alwi, Hasan et. al. (2003). Tata Bahasa Baku Bahasa Indonesia; Edisi Revisi. Jakarta: Balai Pustaka

Kridalaksana, Harimurti. (1982). Kamus Linguistik. Jakarta: Gramedia.

Putrayasa, Ida Bagus. (2008). Analisis Kalimat. Fungsi, Kategori, dan Peran. Bandung: PT. Refika Aditama.

Ramlan, M. (1983). Ilmu Bahasa Indonesia. Sintaksis. Yogyakarta: CV. Karyono.

Redaksi Balai Pustaka. (2005). Pantun Melayu. Jakarta: Balai Pustaka

Robins, RH. (1983). Sistem dan Struktur Bahasa Sunda. Jakarta: Djambatan 
Soebagyo. (1992). Parikan Jawa Puisi Abadi. Yogyakarta: Garda Pustaka

Sudaryat, Yayat. (2014). Struktur Bahasa Sunda. Sintaksis dalam Gamitan Pragmatik. Bandung: Universitas Pendidikan Indonesia. Sekolah Pascasarjana.

Sumarsono, Tatang. Taufik Faturohman. (2008). Gapura Basa VIII; Pangajaran Basa Sunda pikeun Murid SMP/MTs. Bandung: Geger Sunten, Tiga Serangkai Pustaka Mandiri

Verhaar, J.W. M. (1983). Pengantar Linguistik. Yogyakarta: Gadjah Mada University Press.
Wibisana, Wahyu, dkk.. (2000). Lima Abad Sastra Sunda. Bandung: Geger Sunten.

http://lirik.kapanlagi.com/artis/jawa_barat \%252Fsunda/bubuy bulan

\section{UCAPAN TERIMA KASIH}

Ucapan terima kasih yang setinggitingginya penulis haturkan kepada semua pihak yang telah membantu menyelesaikan tulisan ini, kepada yang selalu menjadi penyemangat dan motivasi, serta kepada tim penyunting jurnal LOKABASA. 